ISBN 978-81-936279-5-2

12th International Conference on Business, Education, Humanities and Interdisciplinary Studies

(BEHIS-18)

Zagreb (Croatia) May 11-12, 2018

\title{
Strategy and Tactics of Political Opposition in Contemporary Russia
}

\author{
Roman Savenkov \\ Voronezh State University, Russia
}

\begin{abstract}
The political opposition in contemporary Russia has several levels: non-systemic opposition, parliamentary opposition, intra-elite opposition. The level of the opposition determines the choice of strategy and tactics in Contemporary Russia. Thus, the non-systemic opposition criticizes the government, mobilizes its supporters for collective action, stimulates media attention, but does not have the personnel to replace the ruling elite. In turn, the parliamentary opposition criticizes the actions of the executive, but does not give a critical assessment of the head of state policies. It has a personnel reserve among the deputies of the federal and regional parliaments, but does not have representatives in the executive branch. The parliamentary opposition actively participates in the public space during the parliamentary election campaign. Finally, the intra-elite opposition does not criticize the actions of the ruling group publicly, but has its own corporate interests. The struggle for positions in power structures is usually outside the public space.
\end{abstract}

Keywords: political opposition, political system of Russia, political parties

\section{Introduction}

Political opposition is a broad social phenomenon that arises from the heterogeneity of society and the difference of interests pursued by individuals and social groups. It is generally accepted to consider the opposition in a broad (sensu largo) and narrow sense (senso stricto). In the sensu largo, the opposition is a wide range of emotions, values, views and actions demonstrating disagreement. The senso stricto approach refers to institutionalized subjects of the political process (political parties) that are members of parliament, but do not participate in the formation of the government.

Following the studies of the political opposition, we can single out the following universal features that characterise the political opposition:

- Dissent, i.e. a disagreement with the ruling class over the proposed path of social development or solution to the specific problem;

- Public expression of the disagreement, identification of oneself as an opponent to the authorities;

- Having and offering alternative social development project or the one for solving the problem;

- $\quad$ Staging Protest actions, opposing opposition to authorities;

- Being organized;

- Ability of the subject to establish their own rules in a system of relationships that is relevant to the subject and require counterparties to consider them as a significant factor;

- Struggle for dominant positions in the government;

- Striving for acquiring the institutional form of the party or social movement.

Within the framework of our research we divide actors possessing the features declared above into three groups: 1) protest opposition; 2) parliamentary opposition; 3) inter-elite opposition (G. Gavrilov) [1]. 
The first group, protest opposition, is the leaders of public opinion organizing protest collective actions of citizens. In general, they do not have necessary leaders and sufficient organizational potential for a large-scale replacement of the ruling group. The second - parliamentary opposition - is comprised by faction leaders and active deputies of the national parliament who criticize the course of actions taken by the parliamentary majority in the government. Usually they vote against their legislative initiatives and seek to change the ruling group. The inter-elite opposition is represented by active critics of the political course, occupying significant positions in authority and representing the ruling elite.

The most famous representative of the protest opposition in Russia in 2017 was Aleksey Navalny. His strategy was to create a network of staff capable of holding all-Russian actions on a single topical issue. Being carried out successfully, the all-Russian actions were to raise his status from the "Moscow blogger / lawyer" to a federal politician able to unite the critics of the ruling group in the presidential elections. His participation in the presidential campaign would have allowed Alexey Navalny not only to become more recognised, but also to create an image of a respectable politician with a positive political programme that goes beyond the "street rally activity" in his tactics. After the refusal of the Central Election Commission of Russia to register Alexey Navalny as a presidential candidate, he initiated a strike among voters, offering his supporters to boycott the presidential elections, while simultaneously organizing public observation of the vote [2]. Such tactics allowed him to maintain the interest of the media to his personality and engage in activity 81 campaign headquarters in February-March 2018.

Another strategy was chosen by the former deputy of the State Duma, Dmitry Gudkov. The oppositionist focused on supporting the campaigns of the nominees to the municipal councils of Moscow in September 2017 with the further prospect of his nomination for the mayor of the capital. Meetings with voters within the borders of one constituency came to fruition: Dmitry Gudkov's team received 266 municipal mandates that is more than any other opposition party[3]. Interaction with the candidate for the Presidency of Russia Ksenia Sobchak enabled D. Gudkov to go beyond the political process in Moscow and announce creation of the anti-Putin Party of Change on the basis of the Civil Initiative movement [4]. D. Gudkov organized monitoring of the presidential elections in Moscow and urged his supporters to participate in voting. This tactic demonstrates his modesty and his readiness to interact with the deputies of the United Russia party in the election campaign for the post of the mayor of Moscow [5].

These two examples show that there exists a unified strategy of leaders of non-systemic opposition participation in the elections of important officials to the positions in authority. Although both politicians criticize V. Putin, they have chosen different tactics. Whereas Alexey Navalny has created an organizational base in all major cities of the country for his nomination and support in the presidential elections, Dmitry Gudkov has built the team with the prospect of forming a political party, as well as pursue the post of the mayor of Moscow. At the level of rhetoric, Dmitry Gudkov stands for a tactical coalition with democratic organizations [6] while Alexey Navalny is cautious of merging with ideologically close political groups.

Referential opposition parties in the State Duma (Communist Party of the Russian Federation (CPRF), the Liberal Democratic Party of Russia (LDPR) and Fair Russia) criticize the actions of the government Dmitry Medvedev and on the eve of the federal parliamentary elections proposed alternative programmes [7]. The institutional design of the political system does not allow parliamentary parties to influence political course of the government. This enables parties to use populist rhetoric, seeking to expand their representation in legislative assemblies at the federal and regional levels. Within the framework of this strategy, the parties are forced to engage in a fierce demagogic struggle with each other. At the same time, opposition parties demonstrate a unified support to course in foreign politics taken by President Vladimir Putin.

In Russia opposition inter-elite groups do not dare publicly express alternative views and become a bridge between the street opposition and the ruling elite [8]. The critical standing towards the system of power is held by the former Minister of Finance of the Russian Federation Aleksey Kudrin. Analytical bodies, the Committee of Civil Initiatives and the Center for Strategic Research publish programmes on reforming Russia. Through 
reform projects Aleksey Kudrin seeks to influence political discussions. The former Minister of Economic Development and Trade of the Russian Federation German Gref occupies a critical position in relation to the existing system of public administration. The common strategic feature of the former federal ministers is loyalty to President Putin, moderate criticism of home politics, demonstration of readiness to work on the basis of new modern principles, and a programme of reforms.

Thus, the strategy and tactics of political opposition in Russia are determined by the type of available resources and position in the political system.

\section{References}

[1] G. Gavrilov, Models of political opposition: theoretical and methodological analysis, Thesis for the degree of candidate of political science. 23.00.01. Ekaterinburg, 2003, pp. 28, 37.

[2] The official Internet portal Navalny - 2018, [Online]. Available: https://2018.navalny.com

[3] "Apple revolution": what will the success of Gudkov in the elections in Moscow bring, RBC. - 11/09/2017, [Online]. Available: https://www.rbc.ru/politics/11/09/2017/59b654099a7947246a430af3

[4] Gudkov announced the creation of the Party of Changes together with Sobchak, RBC. - 03/15/2018, [Online]. Available: https://www.rbc.ru/politics/15/03/2018/5aaa98049a7947d12d63f1e1

[5] I am against the boycott, Actual comments. 12/03/2018, [Online]. Available: http://actualcomment.ru/ya-protivboykota-1803121718.html

[6] E. Mukhametshina, Democrats are looking for a way to nominate a single candidate for mayors of Moscow, Vedomosti, 04/04/2018, [Online]. Available: https://www.vedomosti.ru/politics/articles/2018/04/04/755877demokrati-meri

[7] "Ten Steps to a Decent Life" - CPRF, "Socialism - the future of a strong, free and fair Russia" - Fair Russia, the LDPR election program.

[8] K. Rogov Silence of the elites, Novaya Gazeta. May 14, 2012, [Online]. Available: https://www.novayagazeta.ru/articles/2012/05/14/49654-molchanie-elit 